\title{
Perancangan ATS/AMF Berbasis Internet of Things
}

\author{
Andi Wawan Indrawan'),Naely Muchtar' ${ }^{2)}$, Purwito ${ }^{3)}$, Ashar A.R ${ }^{4}$, Ahamad Rizal Sultan ${ }^{5)}$, Ichsan Al \\ Kautsar $\left.{ }^{6}\right)$ \\ 1,2,3,4,5,6 Jurusan Teknik Elektro, Politeknik Negeri ujung Pandang \\ email: andi_wawan@poliupg.ac.id ${ }^{1},:$ maelymuchtar@poliupg.ac.id ${ }^{2},:$ purwitopnup@poliupg.ac.id, \\ ashar_ar@poliupg.ac.id, :rizal.sultan@poliupg.ac.id, : ichsankautsar@gmail.com
}

\begin{abstract}
(요요
Abstract

Penelitian ini bertujuan untuk merancang bangun sebuah perangkat Automatic Transfer Switch/Automatic Main Failure (ATS/AMF) agar suplai listrik ke beban serta energi listrik yang dikonsumsi dapat termonitor dan terjaga kontinuitasnya. NodeMCU Esp32S digunakan sebagai pusat dari sistem kontrol yang secara otomatis mendeteksi dan memastikan ketersediaan suplai listrik dari PLN atau suplai cadangan yaitu Genset. Genset yang digunakan adalah generator 1 phasa yang berkapasitas 8000 Watt dengan tegangan output 220 volt. Informasi terkait konsumsi energi dan suplai listrik yang melayani beban dapat termonitor pada Smartphone Android yang terkoneksi dengan jaringan internet secara real time.. Hasil pengujian rancangan memperlihatkan pengalihan suplai energi listrik ketika terjadi gangguan atau hilang suplai energi listrik dari catu daya utama (PT.PLN) ke catu daya alternatif (Genset) membutuhkan waktu \pm 21 detik, sebaliknya membutuhkan waktu \pm 3 detik pada saat pengalihan ketika catu daya utama kembali normal. Selain itu alat hasil rancangan juga dapat mengoperasikan Genset secara manual melalui Smartphone Android dari jarak berapapun selama alat hasil rancangan terhubung dengan jaringan WiFi.
\end{abstract}

Keywords: GENSET, ATS/AMF, Intenet of Things, NodeMCU Esp32S

\section{PENDAHULUAN}

Ketersediaan energi listrik merupakan salah satu faktor penting ditengah perkembangan teknologi yang sangat pesat. Contohnya untuk keperluan industri, gedung pemerintahan, rumah sakit, dan penyedia layanan komunikasi diperlukan energi listrik yang terus menerus atau kontinyu dalam menjalankan fungsi maupun produksinya.

Dalam menjaga keberlangsungan ketersediaan suplai energi listrik, maka diperlukan sumber energi listrik alternatif seperti Generator Set (Genset) yang berfungsi sebagai back up energi listrik ketika sumber energi listrik utama tidak tersedia. Peralihan dari sumber utama ke sumber cadangan dibutukan sebuah perangkat sistem pengalihan yaitu Automatic Transfer Switch (ATS) atau Automatic Main Failure (AMF).

Pengembangan teknologi dari peralatan ATS/AMF dalam menjaga kontinuitas energi listrik telah banyak dilakukan oleh beberapa peneliti yang disesuiakan dengan kebutuhan yang ada dilapangan seperti pemanfaatan ATS/AMF dalam mengatur suplai energi listrik yang bersumber dari PLN, PLTS dan
Genset untuk melayani beban rumah tangga dengan tipe daya R-1/TR 1300VA[1].

Penelitian terkait ATS/AMF sebagai pengalih catu daya juga dilakukan oleh Mengko [2] yang membangun sistem ATS berdasarkan arus instalasi kapal berbasis mikrokontroler AVR.dengan yang dikendalikan oleh PLC (Programmable Logic Controller).

Pemanfaatan PLC sebagai pengendali ATS/AMF juga dilakukan oleh Hasafuu [3] dengan menggunakan PLC Zelio. Sama halnya dengan Fathur Rahman [4] yang menggunakan PLC Zelio sebagai kendali pengalihan catu daya utama dengan dua sumber catu daya alternatif yaitu Genset dan Fotovoltaik. Akan tetapi untuk pembacaan besaran tegangan dan frekuensi masih membutuhkan mikrokontroler ATmega328. Selain itu pengukuran besaran tegangan di berlakukan batas overvoltage sebesar $230 \mathrm{~V}_{\mathrm{ac}}$ dan undervoltage sebesar 200 $\mathrm{V}_{\mathrm{DC}}$ serta berada pada batas tidak kurang dari $49,5 \mathrm{~Hz}$ dan tidak lebih dari $51 \mathrm{~Hz}$. Dalam peralihan dari sumber energi atau catu daya utam ke Genset memerlukan waktu 10 detik 
dan PV mengisi peralihan tersebut sampai Genset siap untuk dibebani.

Pemanfaatan jaringan internet untuk memonitoring dan mengendalikan ATS/AMF dilakukan oleh A.W Indrawan[5] yang memanfaatkan mikrokontroler ATMega16 sebagai otak dari sistem pengendali. Hasil dari penelitian tersebut memperlihatkan besaran listrik dan catu daya yang melayani beban dapat di monitor dan dikendalikan melalui web. Kontrol dan monitor ATS/AMF jarak jauh juga dilakukan oleh Robinson Pakpahan dkk [6] dimana pengendali ATS/AMF yang dibangun menggunakan mikrokontroler Arduino uno dan aplikasi Extreme Programming.

Berdasarkan kajian terkait ATS/AMF diatas, dalam artikel ini akan mengkaji sistem ATS/AMF yang juga memanfaatkan internet sebagai infrastruktur untuk memonitor beban, sumber energi yang melayani beban, dan mengendalikan on/off Genset melalui aplikasi yang berjalan pada iOS Android. Dengan kata lain perangkat ATS/AMF yang dikembangkan ini bebasis Internet of Things (IoT).

\section{TINJAUAN PUSTAKA}

\section{ATS/AMF}

ATS yaitu sebuah rangkaian listrik yang memiliki fungsi sebagai saklar yang beroperasi otomatis jika terjadi pemadaman arus listrik secara mendadak atau terencana, maka secara otomatis sistem ATS akan bekerja secara otomatis untuk memindahkan suplai sumber listrik dari sumber PLN ke Genset atau sebaliknya

Sedangkan pada $A M F$, adalah sebuah modul rangkaian listrik yang bekerja secara otomatis untuk menghidupkan dan mematikan Genset. Sistem kerjanya adalah apabila listrik PLN mati maka modul $A M F$ langsung menyalakan Genset secara otomatis dan mengalirkan aliran listrik, dan begitu pula sebaliknya apabila listrik PLN hidup maka secara otomatis modul $A M F$ akan mematikan Genset[7].

Secara garis besar, sistem ATS/AMF diperlihatkan pada gambar 1. ATS/AMF akan membaca besaran arus dan tegangan dari masing-masing catu daya dan menentukan catu daya atau sumber energi mana yang siap untuk melayani beban. Selanjutnya sistem akan menyalurkan sumber energi yang tersedia ke beban dengan meghubungkan catu daya ke beban melalui saklar catu daya. Jika yang catu daya utama tidak tersedia maka sistem ATS/AMF akan menyalakan genset melalui perintah starting dan selanjutnya saklar catu daya geneset di on-kan untuk menghubungkan genset dengan beban.

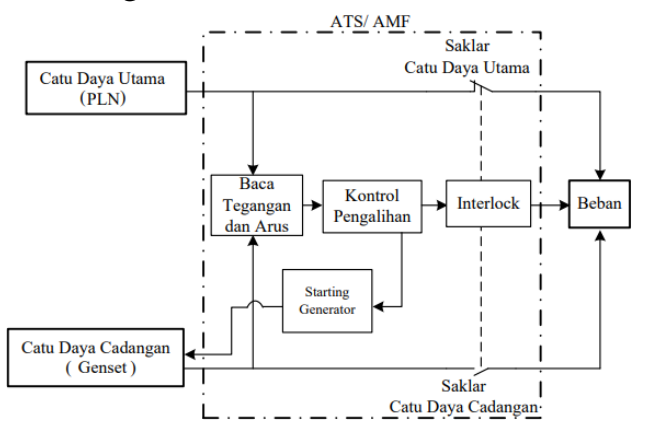

Gambar 1. Diagram Block Sistem ATS/AMF Sumber: (Indrawan, A, W., dkk. 2016)

\section{GENSET}

Genset atau generator set terdiri dari satu set peralatan gabungan engine sebagai penggerak dan generator atau alternator yang berfungsi membangkitkan energi listrik[8]. Genset biasa digunakan sebagai sistem cadangan listrik atau sumber daya yang tergantung atas kebutuhan pemakai.

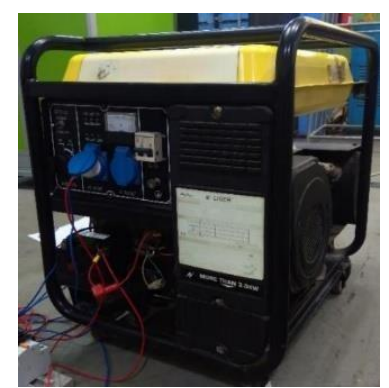

Gambar 2. Generator set 1 fasa

Spesifikasi genset yang digunakan seperti diperlihatkan pada gambar 2 tertera pada tabel 1 yaitu sebagai berikut:

Tabel 1. Spesifikasi generator 1 fasa 


\begin{tabular}{|l|c|}
\hline \multicolumn{2}{|c|}{ Spesifik Item } \\
\hline Rated Voltage & $230 \mathrm{~V}$ \\
\hline Rated Frequency & $50 \mathrm{~Hz}$ \\
\hline Rated Current & $31,1 \mathrm{~A}$ \\
\hline Rated Output & $7200 \mathrm{~W}$ \\
\hline Net Weight & $57 \mathrm{Kg}$ \\
\hline Max rpm & 3600 \\
\hline Starting System & $\begin{array}{c}\text { Recoil/Electric } \\
\text { Starter }\end{array}$ \\
\hline Tank Capacity & $19 \mathrm{~L}$ \\
\hline
\end{tabular}

\section{Internet of Things}

Internet of Things merupakan segala aktifitas yang pelakunya saling berinteraksi dan dilakukan dengan memanfaatkan jaringan internet atau memanfaatkan internet sebagai infrastruktur utama dalam menghubungkan objek-objek tertentu [9]. Dalam penggunaannya Internet of Things di era 4.0 ini mulai banyak ditemui di berbagai aktifitas, seperti mengontrol mesin produksi, peralatan elektronik, dan benda nyata apa saja yang sudah diberikan identitas dan dapat diolah di sistem komputer dan dapat di representasikan dalam bentuk data di sebuah sistem mikrokontroller.

Cara kerja Internet of Things yaitu dengan cara memanfaatkan sebuah argumentasi pemograman yang dimana perintah argumennya itu menghasilkan komunikasi antara sesama mesin yang terhubung secara otomatis tanpa campur tangan manusia dan dalam jarak berapa pun selama mesin dan mikrokontroller masih terhubung dengan jaringan internet, sementara manusia hanya bertugas sebagai pengatur dan pengawas bekerjanya alat tersebut secara langsung[10].

\section{Blynk}

Blynk adalah platform yang memungkinkan dengan cepat membangun interface untuk mengendalikan dan memantau proyek Hardware dari $i O S$ dan perangkat Android. Pada aplikasi Blynk, kita dapat membuat dashboard proyek dan mengatur tombol, slider, grafik, dan Widget lainnya ke layar. Menggunakan Widget,
"Blynk sangat cocok untuk antarmuka dengan proyek-proyek $I O T$ sederhana seperti pemantauan suhu atau menyalakan lampu dan mematikan dari jarak jauh. Blynk adalah Internet of Things yang dirancang untuk membuat remote control dan data sensor membaca dari perangkat arduino ataupun esp8266 degan cepat dan mudah. Blynk bertujuan untuk mengakses perangkat kita dari mana saja melalui smartphone"[11].

Adapun tujuan penggunaan aplikasi Blynk pada perancangan ini yaitu sebagai interface untuk mengendalikan dan memantau proyek Hardware dari perangkat smartphone Android. Nodemcu ESP32S

ESP32S merupakan sebuah board pengembangan yang berbasis pada ESPWROOM3232s, yang merupakan komponen teknologi tinggi, khususnya untuk menghubungkan sebuah projek apakah itu robotic, industrial atau resintial automation ke jaringan internet secara mudah dan murah. menggunakan bahasa pemrograman Lua untuk membantu dalam membuat prototype produk IoT atau bisa dengan memakai sketch dengan arduino IDE. Pengembangan kit ini didasarkan pada modul ESP-WROOM-32, yang mengintegrasikan GPIO, (Pulse Modulation), I2C, 1-Wire dan $2 A D C$ (Analog to Digital Converter) dengan resolusi 8-bit, Wifi 802.11 $\mathrm{b} / \mathrm{g} / \mathrm{n}$, Bluetooth V4.2, Ethernet dan dual core 32-bit Lx microprocessor semua dalam satu board[12].

Tabel 2. Spesifikasi NodeMCU ESP32S

\begin{tabular}{cc}
\hline Spesifikasi & $\begin{array}{c}\text { NodeMCU } \\
\text { ESP32S }\end{array}$ \\
\hline Tegangan Input & $3.3 \sim 5 \mathrm{~V}$ \\
\hline Tegangan Operasi & $3.3 \mathrm{~V}$ \\
\hline $\begin{array}{c}\text { Digital I/O Pins } \\
\text { (DIO) }\end{array}$ & $28 \mathrm{Pin}$ \\
\hline $\begin{array}{c}\text { Analog Input Pins } \\
\text { (ADC) }\end{array}$ & 8 Pin \\
\hline $\begin{array}{c}\text { Analog Output Pins } \\
\text { (DAC) }\end{array}$ & $2 \mathrm{PIN}$ \\
\hline Flash Memory & $4 \mathrm{MB}$ \\
\hline Clock Speed & $240 \mathrm{Mhz}$ \\
\hline WiFi & IEEE 802.11 \\
\hline
\end{tabular}




\begin{tabular}{cc}
\hline Spesifikasi & $\begin{array}{c}\text { NodeMCU } \\
\text { ESP32S }\end{array}$ \\
\hline & $\mathrm{b} / \mathrm{g} / \mathrm{n} / \mathrm{e} / \mathrm{i}$ \\
\hline Frekuensi & $\begin{array}{c}2.4 \mathrm{GHz}-22.5 \\
\mathrm{Ghz}\end{array}$ \\
\hline USB Port & Micro USB \\
\hline
\end{tabular}

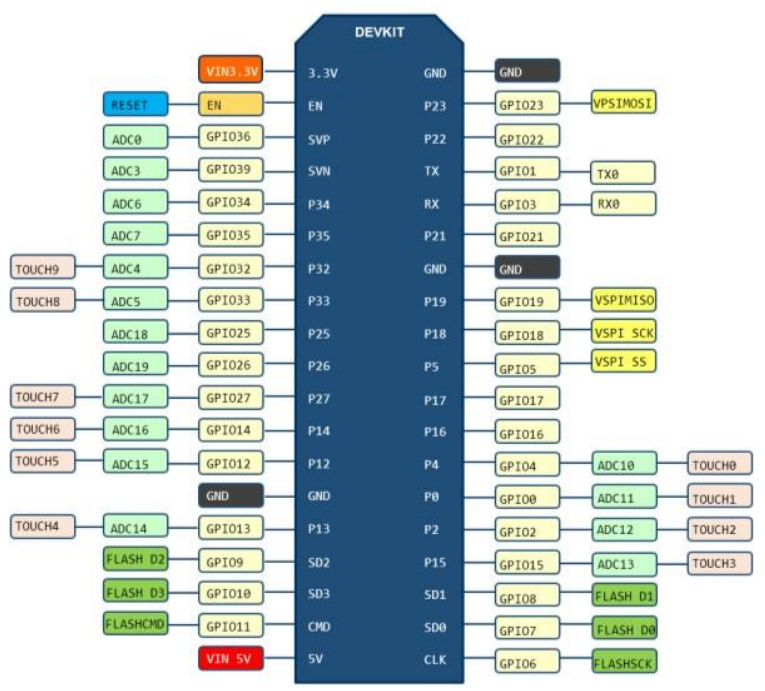

Gambar 2.GPIO NodeMCU ESP32S https://www.shenzhen2u.com/NodeMCU-32S

\section{PZEM-004T}

Modul PZEM-004T adalah sebuah modul sensor multifungsi, yang berfungsi untuk mengukur daya, tegangan, arus, frekuensi, power faktor dan energi yang terdapat pada sebuah aliran listrik. Modul ini sudah dilengkapi sensor tegangan dan sensor arus (CT) yang sudah terintegrasi. Dalam penggunaannya, alat ini khusus untuk penggunaan dalam ruangan (indoor) dan beban yang terpasang tidak diperbolehkan melebihi daya yang sudah ditetapkan[13].

\section{METODE PENELITIAN}

Penelitian ini dilaksanakan di bengkel Teknik listrik dan laboratorium elekronika daya kampus 1 dan 2 Politeknik Negeri Ujung Pandang selama 3 bulan. Pelaksanaan penelitian diawali dengan melakukan survey terhadap generator dan kapasitas beban yang akan dilayani untuk selanjutnya menentukan bahan dan alat yang akan digunakan berupa modul kontroler, Relay dan Kontaktor, MCB, LCD, dan Sensor. Tahapan selanjutnya adalah perancangan hardware dan software, pengambilan data dan pengujian sistem kendali serta analisa hasil kerja dari perancangan.

Langkah pengerjaan peralatan terbagi menjadi tiga yaitu perancangan perangkat keras dan perancangan perangkat lunak untuk selanjutnya diintegrasikan antara hasil perancangan perangkat keras dengan perangkat lunak yang mengacu pada diagram sistem seperti yang ditunjukkan pada gambar 5 berikut.

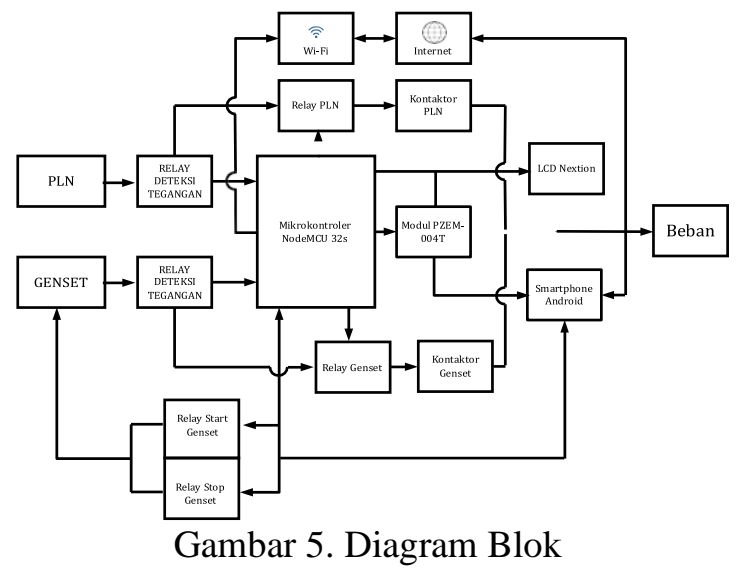

Adapun prosedur kerja dari system yang dibangun diperlihatkan dalam bentuk diagram alir pada gambar 6 . 


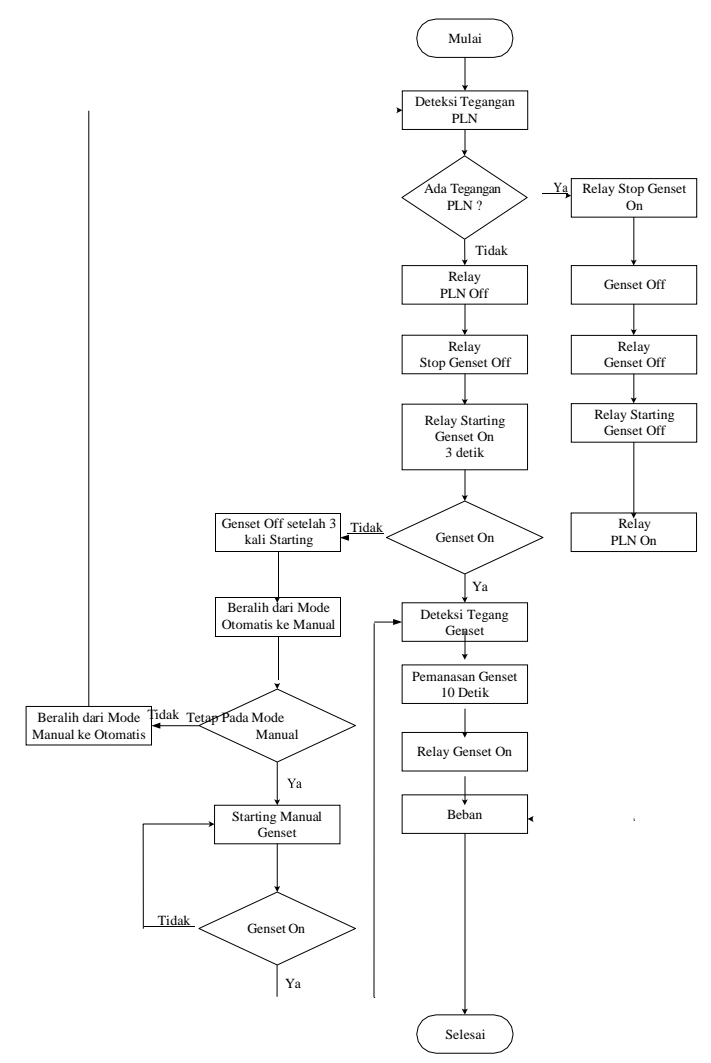

Gambar 6. Flowchart Sistem ATS/AMF yang dirancang

Sistem kerja ATS/AMF yang dibangun adalah jika ATS/AMF mendeteksi tegangan dari suplai PLN maka sistem akan bekerja dengan mengaktifkan Relay Stop Genset, menonaktifkan Relay Genset dan Relay Start Genset, serta mengaktifkan Relay PLN untuk meyuplai ke beban.

Sebakiknya, ketika alat tidak mendeteksi tegangan dari suplai PLN maka sistem akan bekerja dengan menonaktifkan Relay PLN dan Relay Stop Genset, selang beberapa detik kemudian sistem akan mengatifkan Relay Starting selama 3 detik untuk mengoperasikan Genset sebagai suplai cadangan. Jika Genset sudah On, maka Relay deteksi tegangan Genset akan aktif, setelah itu Genset akan dipanasakan selama 10 detik, sebelum Relay Genset aktif untuk menyuplai tegangan ke beban. Tetapi pada saat kondisi Starting jika Genset tidak beroperasi maka sistem akan mengulangi Starting Genset sebanyak 3 kali, jika Genset tidak juga beropersi maka sistem akan mengganti mode operasi dari otomatis ke mode manual, untuk dilakukan maintenance pada Genset.

Dan ketika sumber listrik PLN aktif kembali maka sistem akan bekerja kembali untuk menonaktifkan Relay Genset dan mengaktifkan kembali Relay PLN juga Relay Stop Genset untuk mematikan Genset secara otomatis.

Alat hasil rancangan ini juga selain bisa mengalihkan suplai utama yaitu PLN ke suplai cadangan yaitu Genset seperti penjelasan flowchart pada Gambar 6, alat hasil rancangan ini juga dapat memontoring besaran listrik yang diukur oleh modul PZEM-004T yang akan ditampilkan ke LCD Nextion dan smartphone Android secara real time.

Selain itu alat perancangan ini memungkinkan untuk mengontrol mode operasi sistem baik mode otomatis atau mode manual melalui LCD Nextion dan Smartphone Android. Ketika pada operasi otomatis maka alat hasil rancangan dapat memonitor perpindahan suplai utama ke suplai cadangan atau sebaliknya, dan juga informasi terkait konsumsi energi dari suplai yang melayani beban melalui LCD maupun pada Smartphone Android.

Ketika sistem diatur ke mode manual maka Genset dapat dioperasikan secara manual melalui LCD maupun pada Smartphone android dengan catatan alat yang dirancang dan smartphone Android terhubung dengan jaringan jaringan internet.

\section{HASIL DAN PEMBAHASAN}

Untuk mengetahui unjuk kerja dari hasil rancangan panel ATS/AMF yang dibuat maka dilakukan beberapa tahap pengujian dengan tujuan untuk melihat apakah perangkat keras dan perangkat lunak yang dibangun yang telah dibuat sesuai dengan rancangan. 

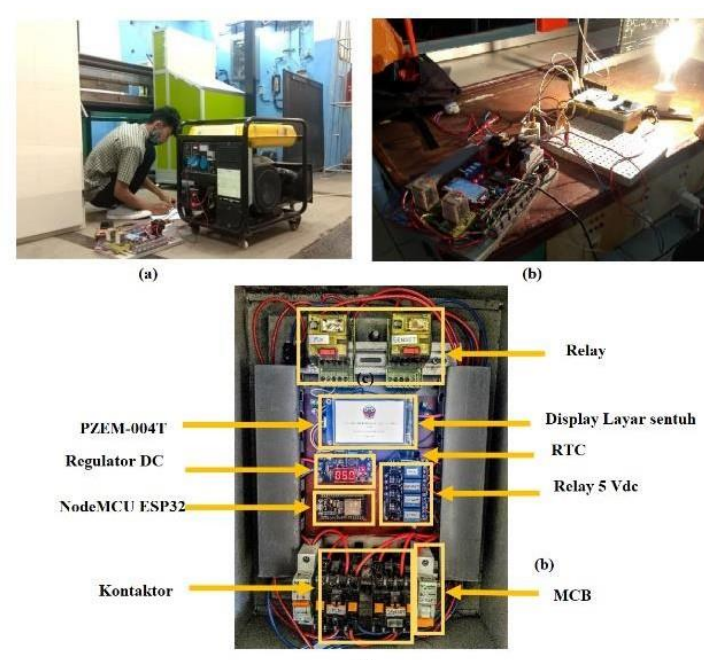

(c)

Gambar 7. Hasil perancangan ATS/AMF: (a) dan (b) Ujicoba genset, (c) Rangkaian kontrol ATS/AMF

Tabel 3. Data Pengujian Relay

\begin{tabular}{|c|c|c|c|c|c|c|c|c|c|}
\hline \multirow[t]{2}{*}{ No } & \multirow{2}{*}{$\begin{array}{l}\text { Tegangan } \\
\text { PLN }\end{array}$} & \multirow{2}{*}{$\begin{array}{c}\text { Tegangan } \\
\text { Genset }\end{array}$} & \multirow{2}{*}{$\begin{array}{l}\text { Relay } \\
\text { PLN }\end{array}$} & \multirow{2}{*}{$\begin{array}{l}\text { Relay } \\
\text { Genset }\end{array}$} & \multirow{2}{*}{$\begin{array}{l}\text { Relay } \\
\text { Start } \\
\text { Gen }\end{array}$} & \multirow{2}{*}{$\begin{array}{l}\text { Relay } \\
\text { Stop } \\
\text { Gen }\end{array}$} & \multicolumn{2}{|c|}{$\begin{array}{l}\text { Waktu } \\
\text { Delay } \\
\text { (Detik) }\end{array}$} & \multirow{2}{*}{ Status } \\
\hline & & & & & & & Relay & Total & \\
\hline 1 & On & Off & On & Off & Off & On & \multicolumn{2}{|c|}{-} & \begin{tabular}{|l|}
$\begin{array}{l}\text { Suplai } \\
\text { didapatkan } \\
\text { dari }\end{array}$ \\
\end{tabular} \\
\hline 2 & Off & Off & On & Off & Off & On & 3 & \multirow{4}{*}{21} & $\begin{array}{l}\text { Suplai dari } \\
\text { PLN } \\
\text { padam }\end{array}$ \\
\hline 3 & Off & Off & Off & Off & Off & On & 5 & & \begin{tabular}{|l|} 
Deteksi \\
tegangan \\
Genset /PLN
\end{tabular} \\
\hline 4 & Off & Off & Off & Off & On & Off & 3 & & $\begin{array}{l}\text { Starting } \\
\text { Genset }\end{array}$ \\
\hline 5 & Off & On & Off & Off & Off & Off & 10 & & $\begin{array}{l}\text { Pemanasan } \\
\text { Genset }\end{array}$ \\
\hline 6 & Off & On & Off & On & Off & Off & \multicolumn{2}{|c|}{-} & $\begin{array}{l}\text { Suplai } \\
\text { didapatkan } \\
\text { dari }\end{array}$ \\
\hline 7 & On & On & Off & On & Off & Off & \multicolumn{2}{|c|}{-} & $\begin{array}{l}\text { Suplai dari } \\
\text { PLN } \\
\text { Aktif kembali }\end{array}$ \\
\hline 8 & On & On & On & Off & Off & On & 3 & 3 & $\begin{array}{l}\text { Mengalihkan } \\
\text { Suplai dari } \\
\text { Genset ke } \\
\text { PLN } \\
\end{array}$ \\
\hline 9 & On & Off & On & Off & Off & On & \multicolumn{2}{|c|}{-} & \begin{tabular}{|l|} 
Genset di \\
matikan dan \\
Suplai \\
didapatkan \\
dari \\
PLN kembali
\end{tabular} \\
\hline
\end{tabular}

Pada tabel 3 diatas bisa dilihat bahwa pada kondisi pertama ketika suplai listrik dari PLN aktif alat ATS/AMF hasil rancangan tidak melakukan pengalihan dari PLN ke GENSET. Namun pada kondisi 2 ketika suplai dari PLN padam, maka secara otomatis sistem akan mendeteksi tegangan selama 8 detik sebelum menonaktifkan Relay Stop Genset, jika tegangan tidak terdeteksi maka Relay Start Genset akan aktif selama 3 detik untuk menghidupkan Genset. Pemanasan Genset berlangsung selama 10 detik sebelum Relay Genset aktif. Urutan proses kerja dapat dilihat pada kondisi 2 sampai dengan kondisi 5 pada tabel 3.

Adapun pada kondisi 6, dimana kondisi Genset masih dalam kondisi Running dan dalam keadaan menyuplai ke beban, dan suplai dari PLN aktif kembali, maka alat akan langsung mendeteksi bahwa suplai utama aktif kembali, lalu proses dilanjutkan pada kondisi 7 dimana sistem akan mengalihkan suplai dari Genset ke suplai utama dengan delay waktu 3 detik sekaligus mengaktifkan Relay selama suplai dari PLN aktif untuk menonaktifkan Genset.

Kondisi dimana sumber dari PLN aktif dan dan padam hingga dialihkan ke Genset dapat dimonitor melalui aplikasi android seperti yang diperlihatkan pada Gambar 8.

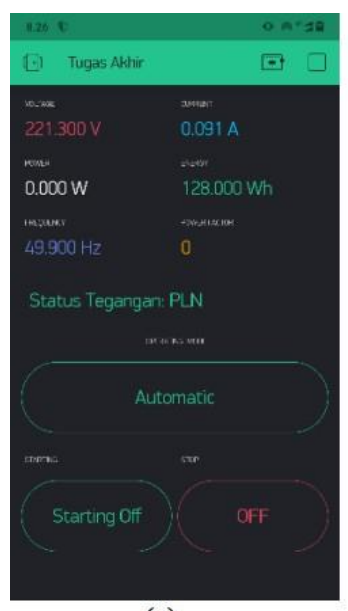

(a)

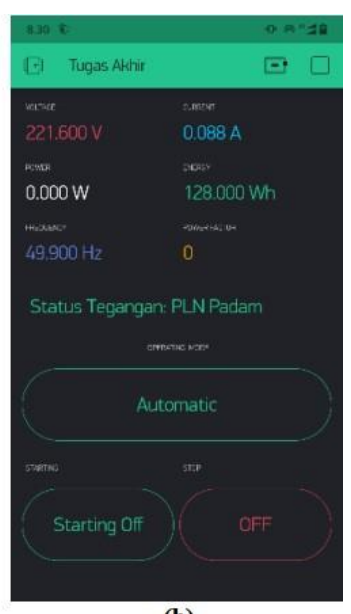

(b)
Gambar 8. (a)Tampilan Aplikasi Android Saat PLN Aktif dan Genset tidak aktif. (b) saat PLN padam dan Genset Aktif

Proses saat sebelum PLN padam hingga genset merespon untuk melakukan proses starting dan mengambil alih suplai listrik ke beban serta kondisi gagal starting juga dapat dimonitor melalui layar sentuh yang terdapat pada panel kontrol seperti diperlihatkan pada Gambar 9 berikut. 


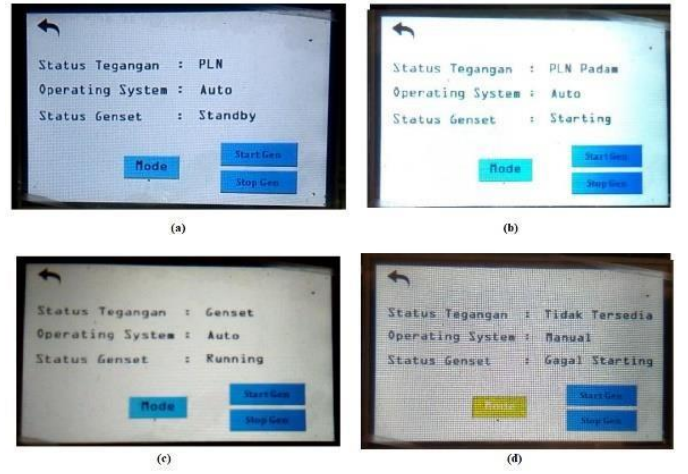

Gambar 9. Status Genset : (a) Stanby, (b) Starting,(c) Running, dan (d) Gagal Starting

Adapun proteksi untuk menghindari Genset melakukan Starting berulang secara terus-menerus maka, pada sistem hasil rancangan ini sudah di program untuk melakukan Starting Genset tidak lebih dari 3 kali Starting sebagai proteksi, dimana jika Genset sudah mengulangi Starting 3 kali maka sistem akan mengalihkan ke mode manual operasi. Adapun hasil pengujian diperlihatkan pada tabel 4 berikut ini:

\begin{tabular}{|c|c|c|c|c|c|c|c|c|}
\hline No & $\begin{array}{c}\text { Tegangan } \\
\text { PLN }\end{array}$ & $\begin{array}{c}\text { Tegangan } \\
\text { Gen }\end{array}$ & $\begin{array}{c}\text { Relay } \\
\text { PLN }\end{array}$ & $\begin{array}{c}\text { Relay } \\
\text { Genset }\end{array}$ & $\begin{array}{l}\text { Relay } \\
\text { Start } \\
\text { Genset }\end{array}$ & $\begin{array}{c}\text { Relay } \\
\text { Stop } \\
\text { Genset }\end{array}$ & $\begin{array}{c}\text { Delay } \\
\text { (Detik) }\end{array}$ & Status \\
\hline 1 & off & off & off & off & off & On & 5 & $\begin{array}{l}\text { Deteksi } \\
\text { Tegangan PLN }\end{array}$ \\
\hline 2 & off & off & off & off & On & off & 3 & Starting Genset \\
\hline 3 & off & off & off & off & off & off & 6 & $\begin{array}{l}\text { Deteksi } \\
\text { Tegangan } \\
\text { Genset }\end{array}$ \\
\hline 4 & off & off & off & off & off & On & 10 & $\begin{array}{l}\text { lenset, off dan } \\
\text { tegangan dari } \\
\text { kembali } \\
\text { melakukan } \\
\text { starting hingga 3 } \\
\text { kali. }\end{array}$ \\
\hline 5 & off & off & off & off & off & off & - & Staring Manual \\
\hline
\end{tabular}

Tabel 4.Pengujian Gagal Starting

Selain dapat memonitor proses peralihan suplai energi baik itu dari sumber PLN maupun Genset dan sebaliknya. Alat yang dibangun juga dapat memonitor besaran energi listrik yang tesedia dan waktu operasi peralatan secara real time seperti yang diperlihatkan pada Gambar 10 berikut:

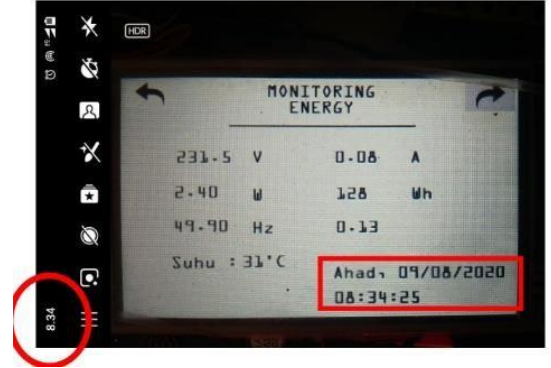

Gambar 10.Tampilan Pada LCD

Nexion Monitoring Energi dan Waktu

\section{KESIMPULAN}

Sebagai kesimpulan dari hasil pengujian, didapatkan hasil bahwa alat dapat bekerja dengan baik dan sesuai dengan fungsinya, dimana alat kontrol ATS/AMF hasil rancangan dapat mengoperasikan generator ketika suplai utama dari PLN mengalami gangguan atau padam dan mematikan Genset ketika suplai PLN kembali aktif. Dari pengujian didapatkan bahwa waktu yang diperlukan untuk perpindahan sumber listik dari PLN ke Genset selama \pm 21 detik. Lamanya waktu yang dibutuhkan dalam peralihan dari PLN ke Genset dikarenakan dibutuhkannya waktu untuk proses starting, pemanasan hingga genset siap untuk dibebani sehingga dibutuhkan waktu lebih lama. Sedangkan peralihan dari Genset ke PLN dapat dilakukan secara lagsung tidak lebih dari 3 detik.

Alat hasil rancangan dapat mengirimkan data melalui aplikasi Android apabila terjadi perpindahan sumber listrik secara otomatis dan juga dapat mengoperasikan Genset secara manual melalui Smartphone Android dari jarak berapapun selama alat hasil rancangan terhubung dengan jaringan $\mathrm{WiFi}$.

\section{REFERENSI}

[1] Asriadi, A.W. Indrawan,.S. Pranoto, AR Sultan, R Ramadhan, Rancang bangun Automatic Transfer Switch (ATS) Pada PLTS dan PLN Serta Genset, 2016, Jurnal elektrika 13(2), pp. 255-235.

[2] A. A. Mengko, L. S. Patras, and F. Lisi, Rancang Bangun Sistem Fleksible ATS (Automatic Transfer Switch) Berdasarkan 
Perubahan Arus Pada Instalasi Listrik Kapal Berbasis Microcontroller, 2016, EJournal Tek. Elektro dan Komput., vol. 5, no. 2, pp. 67-76.

[3] Hasaafu, Ambo, L.O.A.R., Hande, S., Rancang Bangun ATS-AMF Berbasis PLC, 2012, Jurusan Teknik Elektro Politeknik Negeri Ujung Pandang Makassar

[4] F. Rahman, A. Natsir, and G. Wahyu, Rancang Bangun ATS / AMF Sebagai Pengalih Catu Daya Otomatis Berbasis Programmable Logic Control, 2015, Dielektrika, vol. 2, no. 2, pp. 164-172.

[5] A. W. Indrawan, Hamdani, and Nuraminah, Perancangan Sistem Kendali Dan Monitoring ATS/AMF Melalui Jaringan Internet,2016, ELEKTRIKA, vol. 13, no. 2, pp. 117-128.

[6] R. Pakpahan, D. N. Ramadan, and S. Hadiyoso, Rancang Bangun Dan Implementasi Automatic Transfer Switch (ATS) Menggunakan Arduino Uno Dan Relai, 2016., JETT, vol. 3, no. 2, pp. 332341.

[7] Maryanto, I., \& Sikki , M. I. Sistem Automatic Transfer Switch (ATS) Automatic Main Failure (AMF) Menggunakan SMS. 2018, JREC Journal of Electrical and Electronics, 2018, 22.

[8] A.W. Indrawan, Hamdani, \& Aminah, Nur. Rancang Bangun Sistem Kendali dan Monitoring ATS/AMF dalam Pengalihan Sumber Energi Listrik Melalui Jaringan Internet, Prosiding Seminar Teknik Elektro \& Informatika IT_020,2016, pp. 262-263.

[9] Miorandi, Daniele, Sabrina Sicari, Francesco De Pellegrini, And Imrich Chlamtac. Internet of Things: Vision, Applications And Research Challenges. 2012, Ad Hoc Networks 10(7): $1497-$ 1516.

[10] Efendy, Y. Internet of Things (IoT) Sistem Pengendalian Lampu Menggunakan Raspberry PI berbasis Mobile. Jurnal Ilmiah Ilmu Komputer, 2018, pp.20-21.

[11] Ashari, M. A., \& Lidyawati, L. IoT Berbasis Sistem Smart Home Menggunakan Nodemcu V3. Jurnal Kajian Teknik Elektro, 2019, pp. 140-141.

[12] ESPRESSIF, Epressif Systems.com. Espressif,Available https://www.espressif.com/en/esp- wroom-32/resources last accessed: 4 Juni 2020

[13] Habibi, F. N., Setiawidayat, S., \& Mukhsim, M. Alat Monitoring Pemakaian Energi Listrik Berbasis Android Menggunakan Modul PZEM-004T. Prosiding Seminar Nasional Teknologi ElektroTerapan, 2017, 158. 